\title{
Pengaruh Leverage, Earning Variability, Likuidutas dan Kinerja Perusahaan terhadap Risiko Sistematis pada Perusahaan yang Tercatat pada Index LQ 45 di Bursa Efek Indonesia
}

\author{
Siti Ko'imah \\ Sekolah Tinggi Ilmu Ekonomi YPPI Rembang \\ Damayanti \\ Sekolah Tinggi Ilmu Ekonomi YPPI Rembang \\ shoviana.ranti@gmail.com \\ damayanti_rahmania@yahoo.co.id
}

\begin{abstract}
Abstrak
Tujuan dari penelitian ini adalah untuk menguji dan menjelaskan pengaruh leverage, earning variability, likuiditas dan kinerja perusahaan terhadap risiko sistematis pada perusahaan yang tercatat pada Index LQ-45 di BEI. Populasi dari penelitian ini adalah perusahaan yang konsisten tercatat pada Index LQ-45 periode 2014-2018 sebanyak 26 perusahaan. Pengambilan sampel dalam penelitian ini menggunakan teknik purposive sampling yaitu pengambilan sampel dengan kriteria tertentu dan diperoleh sebanyak 11 perusahaan selama 5 tahun, sehingga diperoleh 55 observasi. Berdasarkan uji asumsi klasik data observasi dalam penelitian ini tidak lolos uji autokorelasi dan uji heteroskedastisitas, sehingga diperlukan pengobatan dengan transformasi data menggunakan metode cochrane orcutt yang menyebabkan jumlah observasi berkurang 1 menjadi 54 observasi. Analisis data yang digunakan dalam penelitian ini adalah analisis regresi linier berganda dengan menggunakan uji t. Hasil penelitian ini menunjukkan bahwa leverage dan likuiditas berpengaruh positif signifikan terhadap risiko sistematis. Earning variability berpengaruh negatif tidak signifikan terhadap risiko sistematis dan kinerja perusahan berpengaruh positif tidak signifikan terhadap risiko sistematis. Hasil uji koefisien determinasi menunjukkan nilai 0,285 yang artinya bahwa variabel leverage, earning variability, likuiditas dan kinerja perusahaan mampu menjelaskan variabel risiko sistematis sebesar 28,5\% sedangkan 72,5\% dijelaskan oleh faktor lain di luar model penelitian ini.
\end{abstract}

Kata Kunci: Leverage, Earning Variability, Likuiditas, Kinerja Perusahaan dan Risiko Sistematis. 


\section{Pendahuluan}

Saat ini kesadaran masyarakat akan investasi sudah mulai berkembang, tidak hanya pada sektor riil saja tetapi juga pada sektor keuangan. Menurut Hartono (2017:5), investasi adalah penundaan konsumsi sekarang untuk dimasukkan ke aktiva produktif selama periode waktu yang tertentu. Investasi pada surat berharga mulai dikenal oleh masyarakat di kota-kota besar. Pasar modal merupakan sarana perusahaan untuk meningkatkan kebutuhan jangka panjang dengan menjual saham atau obligasi (Hartono, 2017:29). Investasi di pasar modal telah menjadi pilihan yang menarik. Keberadaan pasar modal memberikan manfaat yang cukup besar bagi suatu negara khususnya negara berkembang seperti negara Indonesia. Pasar modal memberikan kesempatan kepada investor untuk dapat memilih secara bebas sekuritas-sekuritas yang diperdagangkan di pasar modal sesuai dengan preferensi risiko, ketersediaan dana dan jangka waktu investasi.

Investor yang melakukan investasi di pasar modal memiliki kesempatan untuk mendapatkan return sesuai karakteristik investasi yang dipilihnya tanpa mengabaikan risiko dari setiap investasi yang dilakukan. Harapan dan keuntungan dapat berupa tingkat pengembalian atau return yang sesuai dengan besarnya dana yang ditanamkan dalam melakukan keputusan investasi, khususnya pada sekuritas saham, return yang diperoleh berasal dari dua sumber, yaitu deviden dan capital gain, sedangkan risiko investasi saham tercermin dari variabilitas pendapatan (return saham) yang diperoleh (Masdupi dan Noberlin, 2015). Rachmawati dalam Nainggolan dan Solikhah (2016) menjelaskan bahwa dalam pasar modal, baik pasar modal konvensional maupun pasar modal syariah memperdagangkan beberapa jenis sekuritas yang mempunyai tingkat risiko yang berbeda dan salah satunya adalah saham. Sumber risiko investasi muncul dari berbagai faktor, seperti nilai tukar IDR-USD, inflasi, kebijakan pemerintah, siklus bisnis, inovasi teknologi, pertumbuhan ekonomi dan krisis geopolitik. High risk high return, sebuah pepatah dalam dunia investasi. Setiap keputusan investasi memang selalu menyangkut dua hal ini, yaitu risiko dan return.

Risiko mempunyai hubungan positif dengan return yang diharapkan dari suatu investasi sehingga semakin besar return yang diharapkan semakin besar pula risiko yang harus ditanggung oleh investor. Perbedaan risiko yang diharapkan (return yang diantisipasi investor di masa mendatang) dengan return yang benar-benar diterima (return yang diperoleh investor) merupakan risiko yang harus selalu dipertimbangkan dalam proses investasi. Menurut Tandelilin (2017:116) dalam manajemen investasi modern juga dikenal pembagian risiko total investasi ke dalam dua jenis risiko, yaitu risiko tidak sistematis dan risiko sistematis. Risiko tidak sistematis atau dikenal dengan risiko spesifik (risiko perusahaan), risiko perusahaan merupakan risiko yang terkait pada perubahan kondisi mikro perusahaan penerbit sekuritas (contoh: risiko keuangan dan risiko bisnis). Dalam manajemen portofolio disebutkan bahwa risiko perusahaan bisa diminimalkan dengan melakukan diversifikasi aset dalam suatu portofolio.

Sedangkan risiko sistematis atau dikenal dengan risiko pasar, merupakan risiko yang berkaitan dengan perubahan yang terjadi di pasar secara keseluruhan (Tandelilin, 2017:116). Perubahaan tersebut mempengaruhi variabilitas return suatu investasi. Risko sistematis adalah risiko yang tidak bisa diversifikasi karena risiko dipengaruhi oleh faktor-faktor makro yang dapat mempengaruhi perusahaan secara keseluruhan (contoh: risiko pasar, tingkat inflasi dan krisis). Risiko sistematis dilambangkan dengan $\beta$ (beta). Beta menurut Hartono (2017:464) merupakan suatu pengukur volatilitas (volatility) return suatu sekuritas atau return portofolio terhadap return pasar. Beta sekuritas ke-i mengukur volatilitas return sekuritas ke-i dengan 
return pasar. Beta portofolio mengukur volatilitas return portofolio dengan return pasar. Demikian beta merupakan pengukur risiko sistematis dari suatu sekuritas atau portofolio relatif terhadap risiko pasar. Risiko ini berasal dari beberapa faktor fundamental perusahaan dan faktor karakteristik pasar tentang saham perusahaan.

Beaver, et al dalam Hartono (2017:389) mengembangkan penelitian yang menyajikan perhitungan beta dengan menggunakan beberapa variabel fundamental. Variabel-variabel yang dipilih merupakan variabel yang dianggap berhubungan dengan risiko, karena beta merupakan pengukur dari risiko. Variabel yang digunakan meliputi, devidend payout, asset growth, leverage, liquidity, asset size, earning variability dan accounting beta. Hasil penelitian Beaver, et al dalam Hartono (2017:390) menunjukkan bahwa dari tujuh variabel, empat variabel di antaranya yaitu; asset growth, leverage, earning variability dan accounting beta terdapat hubungan yang positif dengan beta saham, sedangkan dua variabel lainnya yaitu dividend payout, liquidity dan asset size terdapat hubungan yang negatif dengan beta.

Terdapat beberapa penelitian terdahulu yang meneliti tentang analisis variabel yang mempengaruhi risiko sistematis atau beta saham selain Beaver, et al (1970) antara lain; Priyanto (2017) yang meneliti tentang pengaruh leverage dan earning variability terhadap beta saham pada Perusahaan Jakarta Islamic Index. Hasil penelitian menunjukkan bahwa leverage berpengaruh positif tidak signifikan terhadap beta saham, sedangkan earning variability mempunyai pengaruh negatif dan signifikan terhadap beta saham. Hasil tersebut berbeda dengan penelitian Nainggolan dan Solikhah (2016) yang menunjukkan bahwa leverage berpengaruh positif signifikan terhadap risiko sistematis, sedangkan earning variability berpengaruh positif tidak signifikan terhadap risiko sistematis.

Werastuti dan Estiyanti (2015) meneliti tentang sumber pembiayaan dari utang dan likuiditas, hasil penelitian menunjukkan bahwa sumber pembiayaan dari utang tidak berpengaruh terhadap beta saham. Likuiditas yang diukur dengan memakai loan to deposit ratio (LDR), bahwa likuiditas berpengaruh negatif dan signifikan terhadap beta saham. Hasil tersebut hampir sama dengan penelitian Masdupi dan Noberlin (2015) tentang pengaruh leverage, likuiditas dan kinerja perusahaan terhadap risiko sistematis dari perusahaan manufaktur yang terdaftar di BEI. Hasil penelitian Masdupi dan Noberlin (2015) menunjukkan bahwa variabel likuiditas dan kinerja perusahaan yang diproksikan dengan EPS berpengaruh negatif signifikan terhadap risiko sistematis, sedangkan variabel leverage berpengaruh negatif tetapi tidak signifikan.

Hasil dari semua penelitian sebelumnya terdapat research gap yaitu perbedaan hasil penelitian atau hasil yang tidak konsisten, hal tersebut dapat terjadi karena perbedaan pengukuran dalam variabel dan populasi penelitian. Oleh sebab itu penelitian ini adalah menguji kembali variabel leverage, earning variability, likuiditas dan kinerja perusahaan sebagai variabel independen yang mempengaruhi beta saham atau risiko sistematis. Objek dari penelitian ini adalah perusahaan yang tercatat pada Index LQ-45 periode 2014-2018. Perusahaan yang tercatat dalam LQ-45 adalah perusahaan yang selama 12 bulan terakhir, ratarata transaksi sahamnya masuk dalam urutan 60 terbesar di pasar reguler dan Selama 12 bulan terakhir, rata-rata nilai kapitalisasi pasarnya masuk dalam urutan 60 terbesar di pasar reguler, sehingga kemungkinan besar menjadi pilihan utama investor untuk berinvestasi. Perusahaanperusahaan yang terdaftar dalam LQ-45 adalah perusahaan dengan ukuran yang besar dan selalu dievaluasi kinerjanya oleh BEI. Harga saham perusahaan LQ-45 juga cenderung lebih cepat bereaksi terhadap perubahan pasar dibandingkan dengan saham yang tidak termasuk dalam Index LQ-45. 
Selama 10 periode yaitu 2014-2018 terdapat 26 perusahaan yang konsisten tercatat pada Index LQ-45. Dari 26 perusahaan yang konsisten tercatat pada Index LQ-45 terdapat 21 perusahaan mengalami beta yang fluktuatif dan 4 perusahaan mengalami kenaikan beta secara berturut-turut selama periode 2014-2018. Ada 1 perusahaan yang tidak konsisten menampilkan data beta selama periode 2014-2018. Rata-rata beta pada perusahaan yang tercatat di Index LQ45 selama periode 2014-2018 cenderung mengalami kenaikan, kecuali pada periode 2017 beta perusahaan Index LQ-45 mengalami penurunan. Periode 2015 rata-rata beta perusahaan Index LQ-45 naik sebesar 2,55\% dari tahun 2014. Periode 2016 beta perusahaan Index LQ-45 naik lagi sebesar 6,07\% dari tahun 2015 .

Semua perusahaan yang konsisten tercatat di Index LQ-45 selama periode 2014-2018 memiliki risiko sitematis atau beta $>1$. Koefesien beta adalah ukuran sensitivitas atau kepekaan individu saham terhadap pergerakan pasar. Perusahaan yang memiliki saham dengan koefesien beta $>1$ umumnya lebih agresif dari pasar. Artinya, jika pasar sedang naik saham tersebut akan mengalami kenaikan yang tinggi dari pasar akan tetapi, jika pasar sedang turun harga pasar akan turun lebih besar dari penurunan pasar. Perusahaan yang memiliki saham dengan koefesien beta $=1$, umumnya mengikuti arus pasar. Artinya, jika saham tersebut mengalami kenaikan yang sama dengan pasar atau Index, demikian pula sebaliknya. Perusahaan yang memiliki saham dengan koefesien beta $<1$, umumnya bergerak lebih lambat dari pasar. Artinya, jika pasar naik, saham tersebut akan mengalami kenaikan namun selalu lebih rendah dari kenaikan pasar, demikan sebaliknyaSesuai latar belakang tersebut maka peneliti melakukan penelitian dengan judul "Pengaruh Leverage, Earning Variability, Likuiditas dan Kinerja Perusahaan terhadap Risiko Sistematis pada Perusahaan yang tercatat pada Index LQ45 di Bursa Efek Indonesia”.

\section{Rumusan Masalah}

Berdasarkan latar belakang tersebut, maka perumusan masalah yang terdapat di penelitian ini adalah sebagai berikut:

1. Bagaimana pengaruh leverage terhadap risiko sistematis pada perusahaan yang tercatat pada Index LQ-45 di Bursa Efek Indonesia?

2. Bagaimana pengaruh earning variability terhadap risiko sistematis pada perusahaan yang tercatat pada Index LQ-45 di Bursa Efek Indonesia?

3. Bagaimana pengaruh likuiditas terhadap risiko sistematis pada perusahaan yang tercatat pada Index LQ-45 di Bursa Efek Indonesia?

4. Bagaimana pengaruh kinerja perusahaan yang diproksikan dengan EPS terhadap risiko sistematis pada perusahaan yang tercatat pada Index LQ-45 di Bursa Efek Indonesia?

\section{Tujuan Penelitian}

Berdasarkan rumusan masalah yang telah dirumuskan, maka tujuan penelitian ini adalah untuk menguji dan menjelaskan pengaruh leverage, earning variability, likuiditas dan kinerja perusahaan terhadap risiko sistematis pada perusahaan yang tercatat pada Index LQ-45 di Bursa Efek Indonesia. 


\section{Landasan Teori}

\section{Capital Asset Pricing Model (CAPM)}

Capital asset pricing model (CAPM) merupakan suatu model yang digunakan untuk mengestimasi return suatu sekuritas. Bentuk standar CAPM pertama kali dikembangkan secara terpisah oleh Sharpe (1964), Litner (1965) dan Mossin (1969), sehingga model ini sering disebut dengan CAPM bentuk Sharpe-Lintner-Mossin. Asumsi-asumsi yang digunakan di model CAPM menurut Hartono (2017:576-577) adalah sebagai berikut:

1. Semua investor memaksimumkan kekayaannya dengan memaksimumkan utiliti harapan dalam satu periode waktu yang sama.

2. Semua investor melakukan pengambilan keputusan investasi berdasarkan pertimbangan antara nilai return ekspektasian dan deviasi standar return dari portofolionya.

3. Semua investor mempunyai harapan yang seragam terhadap faktor-faktor input yang digunakan untuk keputusan portofolio.

4. Semua investor dapat meminjamkan sejumlah dananya (lending) atau meminjam sejumlah dana dengan jumlah yang tidak terbatas pada tingkat bunga bebas risiko.

5. Investor individual dapat menjual pendek berapapun yang dikehendaki.

6. Semua aktiva dapat dijual dan dibeli di pasar dengan cepat dengan harga yang berlaku.

7. Penjualan atau pembelian aktiva tidak dikenai biayai transaksi.

8. Tidak terjadi inflasi

9. Tidak ada pajak pendapatan pribadi sehingga, investor mempunyai pilihan yang sama untuk mendapatkan dividen atau capital gain.

10. Investor individual tidak dapat mempengaruhi harga dari suatu aktiva dengan kegiatan membeli dan menjual aktiva tersebut.

11. Pasar modal dalam kondisi ekuilibrium.

Menurut Jones sebagaimana dijelaskan oleh Hartono (2017:577) ekuilibrium pasar terjadi jika harga-harga dari aktiva berada disuatu tingkat yang tidak dapat memberikan intensif lagi untuk melakukan perdagangan spekulatif. Pengertian lain menurut Husnan (2015:155) CAPM merupakan model untuk menentukam harga suatu asset. Model ini mendasarkan diri pada kondisi ekuilibrium. Dalam keadaan ekuilibrium tingkat keuntungan yang disyaratkan oleh pemodal untuk suatu saham akan dipengaruhi oleh risiko saham tersebut. Risiko disini bukan lagi diartikan sebagai deviasi standar tingkat keuntungan, tetapi diukur dengan beta. Penggunaan parameter ini konsisten dengan dengan teori portofolio yang mengatakan bahwa apabila pemodal melakukan diversifikasi dengan baik, maka pengukur risiko adalah sumbangan risiko dari tambahan saham ke dalan portofolio. Apabila pemodal memegang portofolio pasar, maka sumbangan risiko ini tidak lain adalah beta.

\section{Beta}

Beta merupakan suatu pengukur volatilitas (volatility) return suatu sekuritas atau return portofolio terhadap return pasar. Beta sekuritas ke-i mengukur volatilitas return sekuritas ke-i dengan return pasar. Beta portofolio mengukur volatilitas return portofolio dengan return pasar. Dengan demikian beta merupakan pengukur risiko sistematis dari suatu sekuritas atau portofolio relatif terhadap risiko pasar (Hartono, 2017:464). Volatilitas dapat didefinisikan sebagai fluktuasi dari return-return suatu sekuritas atau portofolio dalam suatu periode waktu tertentu (Hartono, 2017:464). Jika fluktuasi return-return sekuritas atau portofolio secara 
statistik mengikuti fluktuasi dari return-return pasar, maka beta dari sekuritas atau portofolio tersebut dikatakan bernilai 1 .

Jenis-jenis beta menurut Hartono (2017:465), antara lain:

\section{Beta Pasar}

Beta pasar dapat diestimasi dengan mengumpulkan nilai-nilai historis return dari sekuritas dan return dari pasar selama periode tertentu, misalnya selama 60 bulan untuk return bulanan atau 200 untuk return harian.

\section{Beta Akuntansi}

Data akuntansi seperti misalnya laba akuntansi (accounting earning) dapat juga digunakan untuk mengestimasi beta. Beta akuntansi dapat dihitung secara sama dengan beta pasar (yang menggunakan data return), yaitu dengan mengganti data return dengan data laba akuntansi.

3. Beta Fundamental

Beaver, et al dalam Hartono (2017:177) menyajikan perhitungan Beta menggunakan beberapa variabel fundamental. Variabel yang mereka pilih adalah variabel yang berhubungan dengan risiko, di antaranya devidend payout, asset growth, leverage, liquidity, asset size, earning variability dan accounting beta.

\section{Leverage}

Kasmir (2018:151) leverage atau biasa disebut dengan rasio solvabilitas merupakan rasio yang digunakan untuk mengukur sejauh mana aktiva perusahaan yang dibiayai dengan utang. Artinya berapa besar beban utang yang ditanggung oleh perusahaan dibandingkan dengan aktiva yang dimiliki. Leverage diprediksi mempunyai hubungan positif dengan beta (Hartono, 2017:480). Bowman dalam Hartono (2017:480) menggunakan nilai pasar untuk total utang dalam menghitung leverage dan mendapatkan hasil yang tidak berbeda jika digunakan dengan nilai buku. Menurut Gitman dan Zutter yang dijelaskan Priyanto (2017) semakin tinggi rasio leverage semakin besar pula jumlah uang pihak lain yang digunakan untuk menghasilkan keuntungan eksternal (para kreditur).

Rasio leverage diproksikan dengan debt to total asset ratio (DAR). Debt ratio merupakan rasio utang yang digunakan untuk mengukur perbandingan antara total utang dengan total aktiva (Kasmir, 2018:156). Dengan kata lain, seberapa besar aktiva perusahan dibiayai oleh utang atau seberapa besar utang perusahaan berpengaruh terhadap pengelolaan aktiva. Hasil pengukuran apabila rasionya tinggi, artinya pendanaan dengan utang semakin banyak maka semakin sulit bagi perusahaan untuk memperoleh tambahan pinjaman karena dikhawatirkan perusahaan tidak mampu menutupi utang-utang dengan aktiva yang dimiliki perusahaan (Kasmir, 2018:156).

\section{Earning Variability}

Menurut Hartono (2017:481) earning variability merupakan variabilitas laba diukur dengan nilai deviasi standar dari price earning ratio (PER) atau rasio P/E (harga saham dibagi dengan laba perusahaan). Menurut Tandelilin (2017:377) price earning ratio mengindikasikan besarnya rupiah yang harus dibayarkan investor untuk memperoleh satu rupiah earning perusahaan. Tandelilin (2017:377) juga mengemukakan, dalam pendekatan PER atau pendekatan multiplier, investor akan menghitung berapa kali (mulitiplier) nilai earning yang 
tercermin dalam suatu harga saham. PER menggambarkan rasio atau perbandingan antara harga saham dengan earning perusahaan.

Variabilitas dari laba dianggap sebagai risiko perusahaan, sehingga hubungan antara variabel ini dengan beta adalah positif (Hartono, 2017:481). Tingkat rasio PER tinggi sementara harga saham dalam posisi tetap, maka per lembar saham semakin kecil dan juga sebaliknya jika rasio PER meningkat dan laba per lembar saham tetap, maka harga sahamnya akan semakin besar. Misalnya PER suatu saham sebanyak 3 kali berarti harga saham tersebut sama dengan 3 kali nilai earning perusahaan tersebut. Earning variability menggambarkan variabilitas return suatu perusahaan.

\section{Likuiditas}

Weston dalam Kasmir (2018:129) menyebutkan bahwa rasio likuiditas merupakan rasio yang menggambarkan kemampuan perusahaan dalam memenuhi kewajiban (utang) jangka pendek. Artinya apabila perusahaan ditagih, perusahaan akan mampu untuk memenuhi utang tersebut terutama utang yang sudah jatuh tempo. Rasio likuiditas atau sering juga disebut dengan nama rasio modal kerja merupakan rasio yang digunakan untuk mengukur seberapa likuidnya suatu perusahaan. Caranya adalah dengan membandingkan komponen yang ada di neraca, yaitu total aktiva lancar dengan total pasiva lancar (utang jangka pendek) (Kasmir, 2018:130). Penilaian dapat dilakukan untuk beberapa periode sehingga terlihat perkembangan likuiditas perusahaan dari waktu ke waktu.

Kasmir (2018:130) juga mengemukakan terdapat dua hasil penilaian terhadap pengukuran rasio likuiditas, yaitu apabila perusahaan mampu memenuhi kewajibannya, dikatakan perusahaan tersebut dalam keadaan likuid. Sebaliknya, apabila perusahaan tidak mampu memenuhi kewajiban tersebut, dikatakan bahwa perusahaan dalam keadaan Illikuid. Hartono (2017:480) mengemukakan likuiditas diprediksi mempunyai hubungan negatif dengan beta, yaitu secara rasional diketahui bahwa semakin likuid perusahaan, semakin kecil risikonya.

\section{Kinerja Perusahaan}

Bagi para investor, analisis perusahaan merupakan informasi yang dianggap mendasar dan berguna untuk menggambarkan prospek earning perusahaan di masa depan (Tandelilin, 2017:367). Oleh karena itu, penilaian kinerja perusahaan memberikan informasi kepada investor dalam melakukan investasi pada perusahaan. Komponen pertama yang harus diperhatikan dalam analisis perusahaan adalah laba per lembar saham atau dikenal sebagai earning per share (EPS).

Rasio laba per lembar saham (earning per share) merupakan rasio untuk mengukur keberhasilan manajemen dalam mencapai keuntungan bagi pemegang saham (Kasmir, 2018:207). Menurut Tandelilin (2017:366) EPS merupakan komponen utama dalam penentuan nilai intrinsik saham, ketika EPS meningkat maka harga saham juga meningkat. Selanjutnya, kinerja perusahaan yang bagus, maka laba yang diperoleh akan meningkat dan meningkatkan EPS. Tingginya earning per share menunjukkan kinerja perusahaan yang bagus dan dapat menambah minat investor untuk berinvestasi (Masdupi dan Noberlin, 2015). Pertumbuhan earning hanya akan dicapai oleh perusahaan yang berani menangggung risiko, sehingga perusahaan yang mengalami fluktuasi earning yang tinggi dianggap mempunyai risiko yang 
tinggi. Demikian dapat disimpulkan bahwa kinerja perusahaan berpengaruh positif terhadap risiko sistematis.

\section{Pengembangan Hipotesis}

\section{Pengaruh Leverage terhadap Risiko Sistematis}

Rasio leverage atau biasa disebut dengan rasio solvabilitas menurut Kasmir (2018:151) merupakan rasio yang digunakan untuk mengukur sejauh mana aktiva perusahaan yang dibiayai dengan utang. Bowman seperti yang dikutip dalam Hartono (2017:480) menggunakan nilai pasar untuk total utang dalam menghitung leverage dan mendapatkan hasil yang tidak berbeda jika digunakan dengan nilai buku. Leverage diprediksi mempunyai hubungan positif dengan beta (Hartono, 2017:480). Penggunaan utang yang tinggi akan meningkatkan keuntungan yang diharapkan, namun utang yang tinggi juga akan meningkatkan risiko (Hanafi, 2017:337). Hal tersebut sesuai teori dengan CAPM yang merupakan model untuk menentukan harga suatu aset. Teori CAPM mendasarkan diri pada kondisi ekuilibrium, dalam kondisi ekuilibrium tingkat keuntungan yang disyaratkan oleh pemodal untuk suatu saham dipengaruhi oleh risiko saham tersebut (Husnan, 2015:155).

Gitman dan Zutter dalam Priyanto (2017) mengemukakan apabila leverage semakin tinggi sementara jumlah aktiva tidak berubah maka risiko kegagalan perusahaan untuk mengembalikan pinjaman tinggi dan sebaliknya. Hal tersebut didukung penelitian Nainggolan dan Solikhah (2016) bahwa leverage berpengaruh positif dan signifikan terhadap risiko sistematis. Berdasarkan uraian tersebut maka dapat dirumuskan hipotesis sebagai berikut.

$\mathrm{H}_{1}$ : Diduga leverage berpengaruh positif signifikan terhadap risiko sistematis.

\section{Pengaruh Earning Variability terhadap Risiko Sistematis.}

Earning variability merupakan variabilitas return suatu perusahaan. Besarnya earning variability suatu perusahaaan diukur dengan besarnya penyimpangan PER. Darmaji dan Fakhrudin dalam Priyanto (2017) mengemukakan semakin besar standar deviasi dari PER menunjukkan semakin fluktuatif earning perusahaan tersebut, sehingga akan memperkecil kepastian pengembalian investasi.

Variabilitas dari laba dianggap sebagai risiko perusahaan, sehingga hubungan antara earning variability dengan beta adalah positif (Hartono, 2017:481). Apabila nilai earning variability tinggi maka mencerminkan risiko atas saham suatu perusahaan juga tinggi. Hal tersebut sesuai teori CAPM yang mendasarkan diri pada kondisi ekuilibrium, dalam kondisi ekuilibrium tingkat keuntungan yang disyaratkan oleh pemodal untuk suatu saham dipengaruhi oleh risiko saham tersebut (Husnan, 2015:155). Teori tersebut didukung penelitian Ridwan dan Hasanah (2015) tentang pengaruh variabilitas laba terhadap beta saham, bahwa earning variability terbukti berpengaruh positif signifikan terhadap beta saham. Penelitian Silalahi (2015) juga menunjukkan bahwa variabel PER berpengaruh positif terhadap risiko sistematis. Berdasarkan uraian tersebut maka dapat dirumuskan hipotesis sebagai berikut.

$\mathrm{H}_{2}$ : Diduga earning variability berpengaruh positif signifikan terhadap risiko sistematis. 


\section{Pengaruh Likuiditas terhadap Risiko Sistematis.}

Weston dalam Kasmir (2018:129) menyebutkan bahwa likuiditas merupakan rasio yang menggambarkan kemampuan perusahaan dalam memenuhi kewajiban (utang) jangka pendek. Kasmir (2018:130) juga mengemukakan terdapat dua hasil penilaian terhadap pengukuran rasio likuiditas, yaitu apabila perusahaan mampu memenuhi kewajibannya, dikatakan perusahaan tersebut dalam keadaan likuid. Sebaliknya, apabila perusahaan tidak mampu memenuhi kewajiban tersebut, dikatakan bahwa perusahaan dalam keadaan illikuid.

Hartono (2017:480) mengemukakan likuiditas diprediksi mempunyai hubungan negatif dengan beta, yaitu secara rasional diketahui bahwa semakin likuid perusahaan, semakin kecil risikonya. Artinya, rasio lancar yang tinggi menunjukkan kelebihan aktiva lancar (likuiditas tinggi dan risiko rendah), tetapi pengaruhnya buruk terhadap profitabilitas perusahaan. Aktiva lancar secara umum menghasilkan return atau tingkat keuntungan yang rendah dibandingkan aktiva tetap sehingga risiko yang ditanggung juga akan rendah (Hanafi, 2017:37). Hal tersebut sesuai dengan teori CAPM yang mendasarkan pada kondisi ekuilibrium, di mana keuntungan yang diharapkan suatu saham dipengaruhi oleh risiko saham tersebut.

Teori tersebut dibuktikan oleh penelitian Masdupi dan Noberlin (2015) bahwa likuiditas memiliki pengaruh negatif dan signifikan terhadap risiko sistematis perusahaan. Artinya, jika likuiditas perusahaan semakin baik, perusahaan mampu melunasi kewajiban jangka pendeknya tentu risiko sistematis perusahaan semakin rendah. Berdasarkan uraian tersebut maka dapat dirumuskan hipotesis sebagai berikut.

$\mathrm{H}_{3}$ : Diduga likuiditas berpengaruh negatif signifikan terhadap risiko sistematis.

\section{Pengaruh Kinerja Perusahaan terhadap Risiko Sistematis.}

Analisis perusahaan merupakan informasi yang dianggap mendasar dan berguna untuk menggambarkan prospek earning perusahaan di masa depan (Tandelilin, 2017:367). Komponen pertama yang harus diperhatikan dalam analisis perusahaan adalah laba per lembar saham atau dikenal sebagai earning per share (EPS). Variabel EPS atau laba per saham perusahaan menggambarkan kepada investor tentang bagian keuntungan yang dapat diperoleh dalam suatu periode tertentu dengan memiliki suatu saham. Tingginya earning per share menunjukkan kinerja perusahaan yang bagus dan dapat menambah minat investor untuk berinvestasi (Masdupi dan Noberlin, 2015).

Menurut Tandelilin (2017:366) EPS merupakan komponen utama dalam penentuan nilai intrinsik saham, ketika EPS meningkat maka harga saham juga meningkat. Selanjutnya, kinerja perusahaan yang bagus, maka laba yang diperoleh akan meningkat dan meningkatkan EPS. Pertumbuhan earning hanya akan dicapai oleh perusahaan yang berani menangggung risiko, perusahaan yang mengalami fluktuasi earning yang tinggi dianggap mempunyai risiko yang tinggi, sehingga dapat dinyatakan adanya hubungan positif antara risiko dan EPS. Hal tersebut sesuai dengan teori CAPM yang mendasarkan pada kondisi ekuilibrium, di mana tingkat keuntungan yang diharapkan suatu saham dipengaruhi oleh risiko saham tersebut. Teori tersebut dibuktikan oleh penelitian Ratna dan Priyadi (2014) yang menunjukkan bahwa earning per share berpengaruh positif signifikan terhadap beta saham syariah. Berdasarkan uraian tersebut maka dapat dirumuskan hipotesis sebagai berikut.

$\mathrm{H}_{4}$ : Diduga kinerja perusahaan yang diproksikan dengan EPS berpengaruh positif signifikan terhadap risiko sistematis. 


\section{Model Penelitian}

Berdasarkan perumusan hipotesis tersebut, maka model penelitian dalam penelitian ini adalah sebagai berikut:

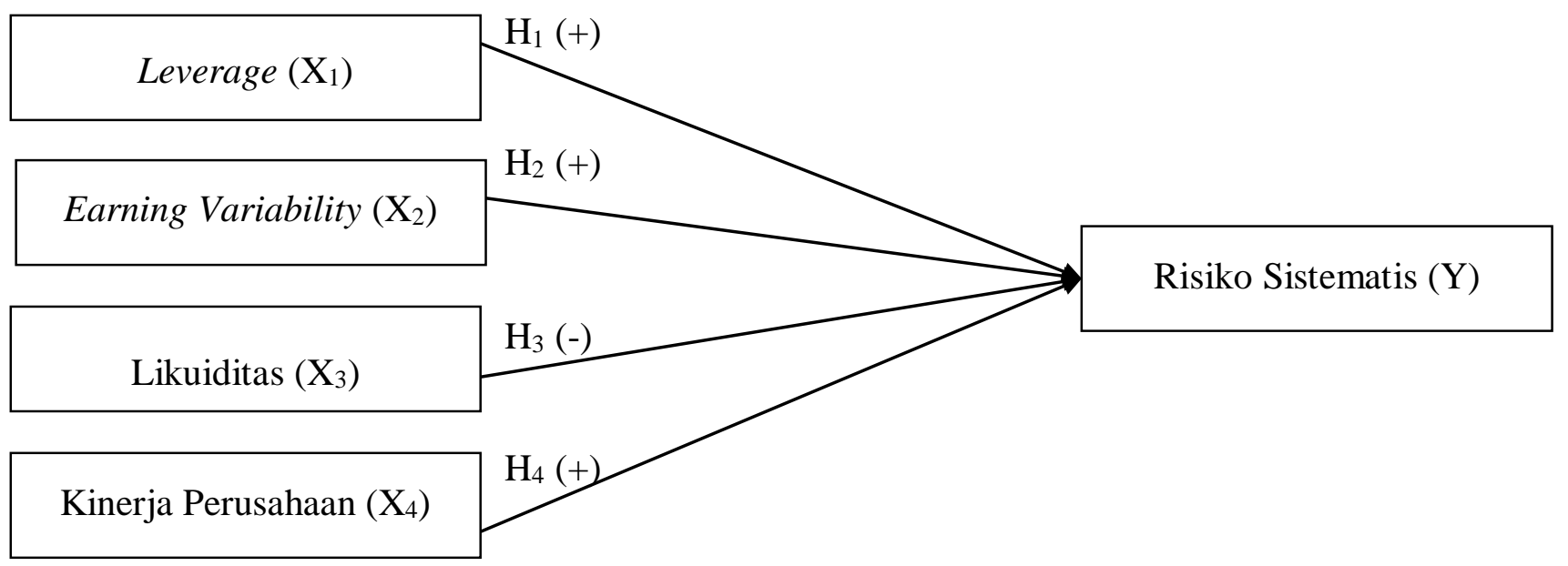

Gambar 1 Model Penelitian

Sumber: Data diolah tahun 2019

\section{Metode Penelitian}

Teknik Pengumpulan data yang digunakan dalam penelitian ini adalah metode dokumentasi. Jenis data yang digunakan dalam penelitian ini adalah data dokumenter berupa laporan tahunan. Sumber data dari penelitian ini menggunakan sumber data sekunder laporan keuangan perusahaan LQ-45 di BEI periode 2014-2018 yang telah diaudit. Data sekunder adalah sumber data penelitian yang diperoleh peneliti secara tidak langsung tetapi melalui Indonesia Capital Market Directory (ICMD), website resmi Bursa Efek Indonesia di www.idx.co.id dan melalui website www.pefindo.com.

Populasi dari penelitian ini adalah perusahaan yang tercatat dalam LQ-45 di Bursa Efek Indonesia untuk periode 2014-2018. Teknik pengambilan sampel menggunakan purposive sampling. Purposive sampling adalah teknik penentuan sampel dengan pertimbangan tertentu (Sugiyono, 2018:138). Adapun kriteria yang ditetapkan untuk memperoleh sampel dalam penelitian ini adalah sebagai berikut:

1. Perusahaan konsisten tergabung dalam Index LQ-45 terdaftar di Bursa Efek Indonesia dan konsisten mempublikasikan laporan keuangan selama periode pengamatan, yaitu periode 2014-2018 secara berturut-turut.

2. Perusahaaan yang mempublikasikan harga saham secara konsisten pada periode 2014-2018.

3. Perusahaan yang konsisten menampilkan data beta di PEFINDO periode 2014-2018.

4. Perusahaan yang menampilkan data tentang DAR, PER, current ratio dan EPS di Indonesia Capital Market Directory periode 2014-2018. 
Tabel 1. Definisi Operasional Variabel

\begin{tabular}{lc}
\hline No & Variabel X dan \\
& Y \\
1. & Leverage (DAR) \\
& \\
2. & Earning \\
& Variability (PER) \\
3. & Likuiditas \\
& (Current Ratio) \\
& Kinerja \\
4. & Perusahaan \\
& (EPS)
\end{tabular}

5.

Risiko Sistematis

(Beta)

\section{Rumus}

$$
\text { DAR }=\frac{\text { Total Utang }}{\text { Total Asset }}
$$

$$
\text { PER }=\frac{\text { Harga Pasar per Lembar }}{\text { Laba per saham }}
$$

Current Ratio $=\frac{\text { Aktiva Lancar }}{\text { Utang Lancar }}$

EPS $=\frac{\text { Laba bersih setelah bunga dan pajak }}{\text { Jumlah saham yang beredar }}$

a. Tahap pertama adalah menghitung return dari setiap saham dan indeks pasar. Rumus perhitungan:

$$
\mathrm{R}_{\mathrm{it}}=\frac{\mathrm{P}_{\mathrm{it}}-\mathrm{P}_{\mathrm{it}-1}}{\mathrm{P}_{\mathrm{it}}}
$$

b. Melakukan regresi antara return harga saham dan return indeks pasar untuk periode 3 tahun terakhir, sehingga mendapatkan nilai raw beta dengan formula perhitungan:

$$
\mathrm{R}_{\mathrm{i}}=\mathrm{a}_{\mathrm{i}}+\beta_{\mathrm{i}} \mathrm{Rm}_{\mathrm{t}}+\mathrm{e}_{\mathrm{it}}
$$

c. Melakukan perhitungan adjusted beta yang digunakan untuk menormalisasikan raw beta agar sesuai dengan karkteristik beta saham yang baik, yaitu mendekati 1 . Rumus perhitungan:

$$
\text { Adjusted Beta }=\frac{2}{3} \times(\text { Raw Beta })+\frac{1}{3} \times(1)
$$

Sumber: Data diolah, 2019

\section{Analisis Regresi Linier Berganda}

Model yang digunakan dalam regresi berganda untuk melihat pengaruh leverage, earning variability, likuiditas dan kinerja perusahaan terhadap risiko sistematis dalam penelitian ini adalah sebagai berikut:

Keterangan:

$$
\mathrm{Y}=\alpha+\mathrm{X}_{1}+\mathrm{X}_{2}+\mathrm{X}_{3}+\mathrm{X}_{4}+\mathrm{e}
$$

$$
\begin{array}{ll}
\mathrm{Y} & =\text { Risiko sistematis (beta) } \\
\alpha & =\text { Konstanta } \\
\beta_{1}, \beta_{2}, \beta_{3}, \beta_{4} & =\text { Koefisien regresi model } \\
\mathrm{X} 1 & =\text { Leverage (current ratio) } \\
\mathrm{X} 2 & =\text { Earning variability (price earning ratio) } \\
\mathrm{X} 3 & =\text { Likuiditas (debt to total asset ratio) } \\
\mathrm{X} 4 & =\text { Kinerja perusahaan (earning per share) } \\
\mathrm{e} & =\text { Residual of error (kesalahan pengganggu) }
\end{array}
$$




\section{Hasil dan Pembahasan}

\section{Deskripsi Statistik}

Perusahaan yang tercatat pada periode 2014-2018 pada Index LQ-45 di Bursa Efek Indonesia berjumlah 66 perusahaan. Dipilihnya 66 perusahaan yang tercatat di Index LQ-45 sebagai populasi dari penelitian ini, karena nilai kapitalisasi pasarnya 45 saham perusahaan yang paling likuid dan memiliki kapitalisasi pasar sangat tinggi yang selalu dievaluasi oleh BEI setiap 6 bulan sekali, sehingga kemungkinan besar menjadi pilihan utama investor untuk berinvestasi. Setelah diseleksi berdasarkan kriteria yang ditetapkan maka diperoleh sampel sebanyak 11 perusahaan. Penentuan sampel menggunakan purposive sampling dengan kriteria yang ditentukan dalam Tabel 2 sebagai berikut.

Tabel 2.

Proses Pemilihan Sampel

\begin{tabular}{lc}
\hline \multicolumn{1}{c}{ Kriteria } & Jumlah \\
\hline Perusahaan yang tercatat pada Index LQ-45 periode 2014-2018 & 67 \\
Perusahaan yang tidak konsisten tercatat pada Index LQ-45 periode 2014-2018 & $\underline{(41)}$ \\
Perusahaan yang konsisten tercatat pada Index LQ-45 periode 2014-2018 & 26 \\
Perusahaan yang tidak konsisten menampilkan data beta di PEFINDO & $(1)$ \\
Perusahaan yang tidak menampilkan current ratio di ICMD & $(9)$ \\
Dikeluarkan karena outlier & $\underline{(5)}$ \\
Jumlah sampel akhir & 11 \\
Jumlah observasi tahun pengamatan (5 tahun) & 55 \\
\hline
\end{tabular}
Sumber: Data diolah tahun 2019.

Berdasarkan jumlah observasi pengamatan tersebut, maka dapat dijelaskan statistik deskriptif dari data penelitian ini. Hasil pengujian statistik deskriptif dari variabel risiko sistematis (beta), DAR, PER, current ratio (CR) dan EPS dari periode 2014-2018 dapat diketahui nilai maksimum, nilai minimum, rata-rata (mean) dan standar deviasi dari setiap variabel. Analisis statistik deskriptif dari penelitian ini dapat dilihat pada Tabel 3.

Tabel 3

Hasil Uji Statistik Deskriptif Metode Chocrane Orcutt

\begin{tabular}{lrrrrr}
\hline & N & \multicolumn{1}{c}{ Min } & \multicolumn{1}{c}{ Max } & \multicolumn{1}{c}{ Mean } & \multicolumn{1}{c}{$\begin{array}{c}\text { Std. } \\
\text { Deviation }\end{array}$} \\
\hline Lag_Beta & 54 & $-0,42$ & 1,25 & 0,5154 & 0,27963 \\
Lag_DAR & 54 & $-19,20$ & 43,42 & 20,0689 & 9,93187 \\
Lag_PER & 54 & $-4,68$ & 34,97 & 9,0243 & 6,94099 \\
Lag_CR & 54 & $-57,31$ & 310,68 & 89,6041 & 70,23882 \\
Lag_EPS & 54 & $-86,76$ & 1476,10 & 263,3025 & 364,79769 \\
Valid N (listwise) & 54 & & & & \\
\hline
\end{tabular}

Sumber: Data diolah, 2019.

\section{Hasil Uji Asumsi Klasik}

Tujuan dari uji asumsi klasik yaitu supaya model regresinya menjadi best linear unbias estimate (BLUE) sehingga menjadi persamaan linear yang paling baik tanpa adanya bias. Ada 
empat uji asumsi klasik yang diterapkan pada model regresi, yaitu uji multikolonieritas, uji autokorelasi, uji heteroskedastisitas dan uji normalitas (Ghozali, 2016:103).

Jumlah observasi yang siap diujikan untuk uji asumsi klasik adalah 55 observasi. Berdasarkan uji asumsi klasik data observasi dalam penelitian ini tidak lolos uji autokorelasi dan uji heteroskedastisitas. Apabila model regresinya terdapat autokorelasi maka menyebabkan variansi sampel tidak dapat menggambarkan variansi populasi. Model regresi yang dihasilkan juga tidak dapat digunakan untuk menduga nilai variabel dependen dari nilai variabel independen tertentu, koefesien regresinya kurang akurat. Sehingga diperlukan pengobatan dengan tranformasi data menggunakan metode cochrane orcutt. Metode cochrane orcutt dipilih karena koefisien autokorelasi $(\rho)$ atau yang disebut dengan istilah "Rho" tidak diketahui (Hidayat, 11 Januari, 2015). Jika menggunakan metode cochrane orcutt jumlah observasinya berkurang 1, sehingga menjadi 54 observasi.

1. Uji Multikolonieritas

Uji multikolonieritas bertujuan untuk menguji apakah model regresi ditemukan adanya korelasi antar variabel independen (variabel bebas). Model regresi yang baik seharusnya tidak terjadi korelasi di antara variabel independen (Ghozali, 2016:103). Adanya multikolonieritas dapat dilihat jika nilai tolerance $\leq 0.10$ dan variance inflation factor (VIF) $\geq 10$.

Tabel 4.

\section{Hasil Uji Multikolonieritas Metode Cochrane Orcutt}

\begin{tabular}{lrrr}
\hline \multicolumn{1}{c}{ Variabel } & Tolerance & VIF & Keterangan \\
\hline Lag_DAR & 0,549 & 1,821 & Tidak Terjadi Multikolonieritas \\
Lag_PER & 0,599 & 1,670 & Tidak Terjadi Multikolonieritas \\
Lag_CR & 0,629 & 1,591 & Tidak Terjadi Multikolonieritas \\
Lag_EPS & 0,759 & 1,318 & Tidak Terjadi Multikolonieritas \\
\hline
\end{tabular}

Sumber: Data diolah, 2019

Nilai tolerance dan VIF pada Tabel 4 menunjukkan bahwa semua variabel independen dalam penelitian ini tidak terjadi multikolonieritas. Hal tersebut ditunjukkan dengan nilai tolerance dari variabel semua variabel independen $>0,10$ dan nilai $\mathrm{VIF}<10$.

\section{Hasil Uji Autokolerasi}

Ghozali (2016:107) menyatakan bahwa uji autokorelasi bertujuan menguji apakah dalam model regresi linier ada korelasi antara kesalahan pengganggu pada periode t-1 (sebelumnya). Untuk menguji apakah antar residual terdapat korelasi yang tinggi digunakan dengan uji run test. Jika antar residual tidak terdapat hubungan korelasi maka dikatakan bahwa residual adalah acak atau random. Run test digunakan untuk melihat apakah data residual terjadi secara random atau tidak sistematis (Ghozali, 2016:116).

Apabila dalam model regresi terdapat masalah autokorelasi maka perlu pengobatan autokorelasi dengan transformasi data menggunakan metode cochrane orcut. Adapun langkahlangkah yang digunakan untuk transformasi data menurut (Hidayat, 11 Januari, 2015) sebagai berikut:

a. Melakukan uji regresi ordinary least squares (OLS) untuk mendapat nilai residual 1 (Res_1).

b. Langkah selanjutnya melakukan transformasi lag pada variabel residual (Res_1) dengan nama Lag_Res. 
c. Melakukan regresi untuk mendapatkan nilai koefisien rho dengan memasukkan hasil perhitungan lag_Res ke dalam variabel independen dan variabel dependen diisi dengan Res_1.

Tabel 5.

Hasil Koefisien Autokorelasi

\begin{tabular}{|c|c|c|c|c|c|}
\hline \multirow[b]{2}{*}{ Model } & \multicolumn{2}{|c|}{$\begin{array}{c}\text { Unstandardized } \\
\text { Coefficients }\end{array}$} & \multirow{2}{*}{$\begin{array}{c}\begin{array}{c}\text { Standardized } \\
\text { Coefficients }\end{array} \\
\text { Beta }\end{array}$} & \multirow[b]{2}{*}{$\mathbf{t}$} & \multirow[b]{2}{*}{ Sig. } \\
\hline & B & Std. Error & & & \\
\hline Lag_Res & 0,536 & 0,118 & 0,533 & 4,548 & 0,000 \\
\hline
\end{tabular}

Sumber: Data diolah, 2019.

Berdasarkan Tabel 5 nilai koefisien rho dapat dilihat pada nilai beta lag_res yaitu sebesar 0,536. Selanjutnya melakukan transformasi cochrane orcutt untuk setiap variabel, langkah-langkahnya sebagai berikut:

1) $L a g \_B e t a=B E T A-(0.536 * \operatorname{Lag}($ BETA $))$.

2) $L a g \_D A R=D A R-(0.536 * \operatorname{Lag}(\mathrm{DAR}))$.

3) Lag_PER $=$ PER $-(0.536 * \operatorname{Lag}(\mathrm{PER}))$.

4) Lag_CR $=\mathrm{CR}-(0.536 * \operatorname{Lag}(\mathrm{CR}))$.

5) $L a g \_E P S=E P S-(0.536 * \operatorname{Lag}(\mathrm{EPS}))$.

d. Setelah mentransformasi variabel idependen dan variabel dependen, maka langkah selanjutnya adalah melakukan regresi ulang dengan variabel baru hasil transformasi data untuk mendapatkan nilai residual. Hasil residual dimasukkan ke dalam uji run test.

Hasil uji autokorelasi Sesudah Metode Cochrane orcutt terdapat pada Tabel 6 sebagai berikut.

Tabel 6

Hasil Uji Autokorelasi Metode Cochrane Orcutt

\begin{tabular}{lr}
\hline \multicolumn{2}{c}{ Unstandardized Residual } \\
\hline $\mathrm{Z}$ & $-0,275$ \\
Asymp. Sig. (2-tailed) & 0,783 \\
\hline
\end{tabular}

Sumber: Data diolah, 2019.

Berdasarkan tabel 6 hasil output SPSS menunjukkan bahwa nilai asymp signifikan 0,783 , yang berarti tingkat signifikansinya $>0,05$. Sehingga dapat disimpulkan bahwa model regresi dalam penelitian ini tidak terjadi autokolerasi karena $\mathrm{H}_{0}$ diterima (residual random) dan menolak $\mathrm{H}_{\mathrm{a}}$ (residual tidak random).

3. Hasil Uji Heteroskedastisitas

Menurut Ghozali (2016:134) uji heteroskedastisitas bertujuan menguji apakah dalam model regresi terjadi ketidaksamaan variance dari residual satu pengamatan ke pengamatan yang lain. Mendeteksi ada atau tidaknya heteroskedastisitas digunakan metode glejser. Menurut Gujarati dalam Ghozali (2016:137) seperti halnya uji park, glejser mengusulkan untuk meregresi nilai absolut residual terhadap variabel independen, dengan melihat nilai probabilitas signifikansinya $>0,05$ maka tidak terjadi heteroskedastisitas. 
INOBIS: Jurnal Inovasi Bisnis dan Manajemen Indonesia Volume 04, Nomor 01, Desember 2020

Siti Ko'imah, Damayanti

Tabel 7

Hasil Uji Heteroskedastisitas Metode Cochrane Orcutt

\begin{tabular}{lcl}
\hline \multicolumn{1}{c}{ Variabel } & Signifikan & \multicolumn{1}{c}{ Keterangan } \\
\hline Lag_DAR & 0,223 & Tidak Terjadi Heteroskedastisitas \\
Lag_PER & 0,282 & Tidak Terjadi Heteroskedastisitas \\
Lag_CR & 0,104 & Tidak Terjadi Heteroskedastisitas \\
Lag_EPS & 0,075 & Tidak Terjadi Heteroskedastisitas \\
\hline
\end{tabular}

Sumber: Data diolah, 2019.

Berdasarkan Tabel 7 dapat dilihat bahwa nilai signifikan dari variabel independen lebih besar dari 5\% (0,05). Sehingga dapat disimpulkan bahwa model regresi dalam penelitian ini tidak mengandung adanya heteroskedastisitas.

\section{Hasil Uji Normalitas}

Uji normalitas bertujuan untuk menguji apakah dalam model regresi, variabel pengganggu atau residual memiliki distribusi normal (Ghozali, 2016:154). Untuk menguji normalitas data setiap data variabel digunakan uji statistik non-parametik kolmogorov smirnov (KS). Uji KS dilakukan jika signifikansi > 0,05 berati data berdistribusi normal. Jika signifikansi $<0,05$ berarti data tidak berdistribusi normal.

\section{Tabel 8}

Hasil Uji Normalitas Metode Cochrane Orcutt

\begin{tabular}{lr} 
Kolmogorov-Smirnov Z & 0,580 \\
\hline
\end{tabular}

Asymp. Sig. (2-tailed) $\quad 0,890$

Sumber: Data diolah, 2019.

Berdasarkan uji normalitas Tabel 8 menunjukkan nilai Asymp signifikan (2-tailed) sebesar 0,890 yang nilainya lebih besar dari 0,05 . Sehingga dapat disimpulkan bahwa model regresi dalam penelitian ini terdistribusi normal.

\section{Hasil Pengujian Hipotesis}

Uji parsial atau uji t digunakan untuk menguji hipotesis diterima atau ditolak. Uji parsial pada dasarnya digunakan untuk mengetahui pengaruh masing-masing variabel independen terhadap variabel dependen (Ghozali, 2016:171). Pengujian dilakukan dengan menggunakan significance level 0,05 $(\alpha=5 \%)$. Pengujian hipotesis untuk model regresi dalam mengetahui nilai $\mathrm{t}_{\text {tabel }}$ diperoleh dari degree of freedom $(\mathrm{df})=\mathrm{n}-(\mathrm{k}+1)$. Di mana $\mathrm{n}=$ jumlah observasi, sedangkan $\mathrm{k}=$ jumlah variabel bebas. Sehingga dalam penelitian ini diperoleh nilai $\mathrm{df}=54-$ $(4+1)=49$, maka nilai tabel yang diperoleh dalam penelitian ini adalah 1,6766 pada derajat signifikan 5\%. Hasil uji hipotesis dapat dilihat pada Tabel 9 sebagai berikut. 
Tabel 9

Hasil Uji Parsial (Uji t)

\begin{tabular}{lrcccc}
\hline \multicolumn{1}{c}{ Model } & \multicolumn{1}{c}{ B } & t Hitung & t Table & Sig. & Keterangan \\
\hline (Constant) & 0,089 & & & & \\
Lag_DAR & 0,012 & 2,757 & 1,6766 & 0,008 & $\mathrm{H}_{1}$ Diterima \\
Lag_PER & $-0,009$ & $-1,485$ & 1,6766 & 0,144 & $\mathrm{H}_{2}$ Ditolak \\
Lag_CR & 0,003 & 4,622 & $-1,6766$ & 0,000 & $\mathrm{H}_{3}$ Ditolak \\
Lag_EPS & $8,264 \mathrm{E}-5$ & 0,808 & 1,6766 & 0,423 & $\mathrm{H}_{4}$ Ditolak \\
\hline
\end{tabular}

Sumber: Data diolah, 2019.

Berdasarkan Tabel 9 hasil uji regresi linier berganda dapat disimpulkan dengan persamaan sebagai berikut:

$$
\begin{aligned}
& \text { Lag_Beta }=\quad 0,089+0,012 \text { Lag_DAR }-0,009 \text { Lag_PER + 0,003 Lag_CR + 8,264E-5 } \\
& \text { Lag_EPS + e }
\end{aligned}
$$

Model persamaan yang dibentuk dapat diinterpretasikan sebagai berikut:

1. Konstanta sebesar 0,089 menyatakan bahwa jika variabel independen dianggap konstan maka rata-rata risiko sistematis (beta) adalah 0,089 .

2. Koefisien regresi leverage (DAR) sebesar 0,012, artinya jika leverage (DAR) mengalami kenaikan sebesar satu satuan, maka risiko sistematis (beta) akan naik sebesar 0,012.

3. Koefisien regresi earning variability (PER) sebesar -0,009, artinya jika earning variability (PER) mengalami kenaikan sebesar 0,009, maka risiko sistematis (beta) akan mengalami penurunan sebesar 0,009.

4. Koefisien regresi likuiditas (CR) sebesar 0,003, artinya jika likuiditas (CR) mengalami kenaikan sebesar satu satuan, maka risiko sistematis (beta) akan naik sebesar 0,003.

5. Koefisien regresi kinerja perusahaan (EPS) sebesar 8,264E-5, artinya jika kinerja perusahaan (EPS) mengalami kenaikan satu satuan, maka risiko sistematis (beta) akan naik sebesar 8,264E-5.

\section{Hasil Uji Koefisien Determinasi}

Koefesien determinasi $\left(\mathrm{R}^{2}\right)$ pada intinya mengukur seberapa jauh kemampuan model dalam menerangkan variasi variabel dependen (Ghozali, 2016:95). Nilai koefisien determinasi adalah antara nol dan satu. Hasil uji koefisien determinasi terdapat pada Tabel 10.

Tabel 10

Hasil Uji Koefisien Determinasi

\begin{tabular}{lcccc}
\hline Model & $\mathbf{R}$ & $\mathbf{R}$ & $\begin{array}{c}\text { Adjusted } \boldsymbol{R} \\
\text { Square }\end{array}$ & Std. Error of the Estimate \\
\hline 1 & $0,582^{\mathrm{a}}$ & 0,339 & 0,285 & \\
\hline
\end{tabular}

Sumber: Data diolah, 2019.

Berdasarkan Tabel 10 menunjukkan bahwa hasil estimasi regresi pada uji koefisien determinasi memperoleh nilai adjusted $\mathrm{R}^{2}$ sebesar 0,285. Artinya, variabel leverage, earning variability, likuiditas dan kinerja perusahaan mampu menjelaskan variabel dependen (risiko 
INOBIS: Jurnal Inovasi Bisnis dan Manajemen Indonesia Volume 04, Nomor 01, Desember 2020

Siti Ko'imah, Damayanti

sistematis) sebesar $28,5 \%$ sedangkan $71,5 \%$ dijelaskan oleh faktor lain yang tidak termasuk dalam model penelitian ini.

\section{Pembahasan}

Berdasarkan hasil analisis data tersebut dapat dibahas beberapa hal sebagai berikut:

\section{Pengaruh Leverage terhadap Risiko Sistematis}

Hasil pengujian hipotesis pertama menunjukkan bahwa leverage berpengaruh positif signifikan terhadap risiko sistematis pada perusahaan yang tercatat pada Index LQ-45 di Bursa Efek Indonesia. Artinya, jika leverage perusahaan naik maka akan berpengaruh pada kenaikan risiko sistematis dan sebaliknya, jika leverage perusahaan turun maka akan berpengaruh pada penurunan risiko sistematis. Semakin tinggi leverage, maka perusahaan menggunakan utang yang besar menunjukkan risiko kebangkrutan yang dialami perusahaan akan tinggi sehingga risiko sistematis perusahaan juga tinggi, sebaliknya jika leverage rendah maka perusahaan menggunakan utang yang kecil, sehingga kebangkrutan yang dialami perusahaan akan rendah.

Hasil penelitian ini sesuai dengan Hartono, (2017:480) leverage berhubungan positif dengan beta saham. Hal tersebut sesuai teori CAPM yang merupakan model untuk menentukan harga suatu aset. Teori CAPM mendasarkan diri pada kondisi ekuilibrium, dalam kondisi ekuilibrium tingkat keuntungan yang disyaratkan oleh pemodal untuk suatu saham dipengaruhi oleh risiko saham tersebut (Husnan, 2015:155). Penggunaan utang yang tinggi akan meningkatkan keuntungan yang diharapkan, namun utang yang tinggi juga akan meningkatkan risiko (Hanafi, 2017:337).

Perusahaan dengan rasio leverage yang rendah, memiliki risiko kecil apabila kondisi perekonomian menurun, tetapi sebaliknya perusahaan dengan rasio leverage yang tinggi memiliki kesempatan untuk mendapatkan profitabilitas yang tinggi, namun risiko yang ditanggung juga tinggi meskipun pada kondisi perekonomian meningkat atau menurun. Gitman dan Zutter dalam Priyanto (2017) leverage semakin tinggi sementara jumlah aktiva tidak berubah maka risiko kegagalan perusahaan untuk mengembalikan pinjaman tinggi dan sebaliknya. Hasil penelitian ini sesuai dengan penelitian Nainggolan dan Solikhah (2016) bahwa leverage berpengaruh positif dan signifikan terhadap risiko sistematis.

\section{Pengaruh Earning Variability terhadap Risiko Sistematis}

Hasil pengujian hipotesis kedua menunjukkan bahwa earning variability berpengaruh negatif tidak signifikan terhadap risiko sistematis pada perusahaan yang tercatat pada Index LQ-45 di Bursa Efek Indonesia. Artinya, earning variability mempunyai hubungan negatif dengan risiko sistematis. Hubungan negatif antara earning variability (PER) dengan risiko sistematis menunjukkan bahwa setiap kenaikan PER akan berpengaruh pada penurunan return saham sekaligus risiko sistematis, tetapi pengaruhnya kecil. Sehingga dari sudut pandang investor PER yang terlalu tinggi dianggap tidak menarik karena mengindikasikan bahwa harga saham tidak akan naik lagi. Begitu sebaliknya penurunan PER akan berpengaruh pada kenaikan return saham sekaligus risiko sistematis, PER yang kecil akan menarik investor untuk berinvestasi karena investor percaya bahwa harga saham akan naik.

Hasil penelitian ini sesuai dengan teori CAPM yang mendasarkan diri pada kondisi ekuilibrium, dalam kondisi ekuilibrium tingkat keuntungan yang disyaratkan oleh pemodal untuk suatu saham dipengaruhi oleh risiko saham tersebut namun pengaruhnya kecil. Hasil 
yang tidak signifikan variabel earning variability (PER) bisa disebabkan perusahaan dalam menginformasikan kinerja perusahaan kurang terbuka dan relevan sehingga dalam menganalisa kinerja perusahaan hasil yang diperoleh kurang akurat (Nainggolan dan Solikhah, 2016).

Hal lain yang menyebabkan PER tidak tercermin dalam perhitungan risiko adalah karena harga saham mungkin belum sepenuhnya mencerminkan nilai intrinsik saham (Fidiana, 2009). Hasil penelitian ini sesuai dengan penelitian Kurniawan dan Mawardi (2018) bahwa earning variability berpengaruh negatif tidak signifikan terhadap risiko sistematis.

\section{Pengaruh Likuiditas terhadap Risiko Sistematis}

Hasil pengujian hipotesis ketiga menunjukkan bahwa likuiditas berpengaruh positif signifikan terhadap risiko sistematis pada perusahaan yang tercatat pada Index LQ-45 di Bursa Efek Indonesia. Artinya, likuiditas memiliki hubungan positif dengan risiko sistematis. Hubungan positif tersebut menunjukkan bahwa kenaikan rasio likuiditas akan berpengaruh pada kenaikan risiko sistematis yang dihadapi perusahaan. Begitu pula sebaliknya bahwa penurunan likuiditas akan berpengaruh pada penurunan risiko sistematis. Semakin tinggi rasio likuiditas mengindikasikan bahwa risiko investasi juga semakin besar, hal tersebut dikarenakan current asset sebagai penghitung atau pembilang dari current ratio tidak hanya meliputi instrumen cash and short term negotiable, akan tetapi juga meliputi account receivable dan inventory yang mengandung risiko besar, itu salah satu alasan Belkaoui dalam Puspitaningtyas (2010) menyatakan bahwa current ratio (CR) bukanlah pengukur likuiditas yang baik.

Hubungan positif antara likuiditas dan risiko sistematis kemungkinan disebabkan karena perusahaan yang menjadi sampel dalam penelitian ini adalah perusahaan yang tercatat pada Index LQ-45 di BEI periode 2014-2018 yang terdiri dari beberapa sektor. Di antaranya ada sektor makanan dan minuman, sektor otomotif, sektor obat farmasi, sektor usaha grosir dan sektor semen. Semua perusahaan terebut memiliki persediaan sebagai aset lancar perusahaan, di mana aset lancar tersebut memiliki risiko yang tinggi karena persedian perusahaan dianggap sebagai aset yang tidak likuid. Hal tersebut disebabkan karena persediaan jika dikonversikan dengan kas membutuhkan waktu yang lama dan kualitas persediaaan akan menurun sehingga mengakibatkan kerugian pada perusahaan.

Hasil penelitian ini berbeda dengan teori CAPM yang mendasarkan pada kondisi ekuilibrium, di mana keuntungan yang diharapkan suatu saham dipengaruhi oleh risiko saham tersebut (Husnan, 2015:155). Artinya, rasio lancar yang tinggi menunjukkan kelebihan aktiva lancar (likuiditas tinggi dan risiko rendah), tetapi pengaruhnya buruk terhadap profitabilitas perusahaan. Aktiva lancar secara umum menghasilkan return atau tingkat keuntungan yang rendah dibandingkan aktiva tetap sehingga risiko yang ditanggung juga akan rendah (Hanafi, 2017:37). Hasil penelitian ini sesuai dengan penelitian Yulia dan Pohan (2015), yang menyatakan bahwa likuiditas berpengaruh positif signifikan terhadap risiko sistematis.

\section{Pengaruh Kinerja Perusahaan terhadap Risiko Sistematis}

Hasil pengujian hipotesis keempat menunjukkan bahwa kinerja perusahaan berpengaruh positif tidak signifkan terhadap risiko sistematis pada perusahaan yang tercatat pada Index LQ-45 di Bursa Efek Indonesia. Artinya, variabel kinerja perusahaan mempunyai hubungan positif dengan risiko sistematis. Hubungan tersebut menunjukkan 
bahwa jika nilai EPS perusahaan meningkat maka akan berpengaruh pada peningkatan risiko sistematis perusahaan, tetapi pengaruhnya kecil. Begitu pula sebaliknya bahwa jika nilai EPS perusahaan turun maka akan berpengaruh pada penurunan risiko sistematis perusahaan tetapi pengaruhnya kecil.

Menurut Tandelilin (2017:366) EPS merupakan komponen utama dalam penentuan nilai intrinsik saham, ketika EPS meningkat maka harga saham juga meningkat. Selanjutnya, kinerja perusahaan yang bagus, maka laba yang diperoleh akan meningkat dan meningkatkan EPS.Tingginya earning per share menunjukkan kinerja perusahaan yang bagus dan dapat menambah minat investor untuk berinvestasi (Masdupi dan Noberlin, 2015).

Pertumbuhan earning hanya akan dicapai oleh perusahaan yang berani menangggung risiko, sehingga perusahaan yang mengalami fluktuasi earning yang tinggi dianggap mempunyai risiko yang tinggi. Hasil penelitian ini sesuai dengan CAPM yang mendasarkan diri pada kondisi ekuilibrium, di mana tingkat keuntungan yang harapkan suatu saham dipengaruhi oleh risiko saham tersebut, sehingga return dan risiko mempunyai hubungan positif namun pengaruhnya kecil.

Tidak terbuktinya hipotesis keempat mungkin disebabkan karena harga saham yang terbentuk tidak ditentukan berdasarkan perolehan earning semata. Hasil penelitian ini menunjukkan bahwa dalam menilai return dan risiko serta prospek masa depan perusahaan, investor belum mempertimbangkan EPS (Fidiana, 2009). Hal tersebut menunjukkan bahwa investor menganggap laba perusahaan yang sudah go public akan selalu stabil. Hasil penelitian ini sesuai dengan penelitian Fidiana (2009) yang menyatakan bahwa EPS berpengaruh positif tidak signifikan terhadap risiko sistematis.

\section{Simpulan}

Berdasarkan pemaparan hasil penelitian ini pada bab sebelumnya, maka dapat diambil simpulan sebagai berikut:

1. Variabel leverage berpengaruh positif signifikan terhadap risiko sistematis pada perusahaan yang tercatat pada Index LQ-45 di Bursa Efek Indonesia. Hal tersebut menunjukkan jika nilai leverage meningkat maka akan berpengaruh pada peningkatan risiko sistematis, begitu pula sebaliknya jika nilai leverage turun maka akan berpengaruh pada penurunan risiko sistematis.

2. Variabel earning variability berpengaruh negatif tidak signifikan terhadap risiko sistematis pada perusahaan yang tercatat pada Index LQ-45 di Bursa Efek Indonesia. Hal tersebut menunjukkan jika nilai PER meningkat maka akan berpengaruh pada penurunan risiko sistematis, tetapi pengaruhnya kecil. Begitu pula sebaliknya jika nilai PER turun maka akan berpengaruh pada kenaikan risiko sistematis.

3. Variabel likuiditas berpengaruh positif signifikan terhadap risiko sistematis pada perusahaan yang tercatat pada Index LQ-45 di Bursa Efek Indonesia. Hal tersebut menunjukkan bahwa semakin likuid perusahaan maka akan berpengaruh pada peningkatan risiko sistematis, begitu pula sebaliknya jika nilai likuiditas turun maka akan berpengaruh pada penurunan risiko sistematis.

4. Variabel kinerja perusahaan berpengaruh positif tidak signifikan terhadap risiko sistematis pada perusahaan yang tercatat pada Index LQ-45 di Bursa Efek Indonesia. Hal tersebut menunjukkan jika nilai EPS perusahaan meningkat maka akan berpengaruh pada kenaikan 
risiko sistematis, tetapi pengaruhnya kecil. Begitu pula sebaliknya jika nilai EPS turun maka akan berpengaruh pada penurunan risiko sistematis.

\section{Daftar Pustaka}

Fidiana, 2009, "Nilai-nilai Fundamental dan Pengaruhnya terhadap Beta Saham Syariah pada Jakarta Islamic Indeks", Ekuitas, Vol XIII, No.1 ISSN: 1411-0398.

Ghozali, Imam, 2016, Aplikasi Analisis Multivariete Dengan Program IBM SPSS 23, Edisi 8, Badan Penerbit UNDIP, Semarang.

Hanafi, Mamduh M., 2017, Manajemen Keuangan, Edisi 2, BPFE, Yogyakarta.

Hartono, Jogiyanto, 2017, Teori Portofolio dan Analisis Investasi, Edisi 11, BPFE, Yogyakarta.

Hidayat, Anwar. (2015, 11 Januari). Cochrane Orcutt Mengatasi Autokorelasi. Diakses pada 14 Oktober 2019, dari https://www.statistikian.com/2015/01/cochraneorcutt.html?amp $=1$

Husnan, Suad, 2015, Dasar-dasar Teori Portofolio dan Analisis Sekuritas, Edisi 5, UPP STIM YKPN, Yogyakarta.

Kasmir, 2018, Analisis Laporan Keuangan, Edisi 1, PT RAJAGRAFINDO PERSADA, Depok.

Kurniawan, Ainur Rofiq dan Imron Mawardi, 2018, "Pengaruh Variabel Akuntansi Perusahaan terhadap Risiko Beta Saham Perusahaan yang tercatat di Jakarta Ilamic Index periode 2012-2016", Jurnal Ekonomi Syariah Teori dan Terapan, Vol V, No. 9

Masdupi, Erni dan Sylvia Noberlin, 2015, "Pengaruh Leverage, Likuiditas dan Kinerja Perusahaan terhadap Risiko Sistematis dari Perusahaan Manufaktur yang terdaftar di BEI”, Jurnal Kajian Manajemen Bisnis, Vol. IV. No.2.

Nainggolan, Nuryana dan Badingatus Solikhah, 2016, "Pengaruh Asset Growth, Leverage dan Earning Variabilty terhadap Risiko Sistematis", Accounting Analysis Journal, Vol V. No. 2 ISSN 2252-6765.

Priyanto, Sugeng, 2017, "Pengaruh Asset Growth, Leverage dan Earning Variability terhadap Beta Saham pada Perusahaan yang Bergabung dalam Jakarta Islamic Index di BEI”, Jurnal Ekonomika dan Manajemen, Vol VI. No.1 ISSN: 2252-6226.

Puspitaningtyas, Zarah, 2010, "Manfaat Informasi Akuntansi untuk Mempredeksi Risiko Investasi Saham Berdasarkan Pendekatan Desicion Esefulness", Jurna Akuntansi Multiparadigma, Vol I, No. 3.

Ratna, Anggi Marshita dan Maswar Patuh Priyadi, 2014, "Pengaruh Faktor Fundamental dan Variabel Makro Ekonomi terhadap Beta Saham Syariah", Jurnal Ilmu dan Riset Akuntansi, Vol III. No. 7.

Ridwan, Nur dan Nuramalia Hasanah, 2015, "Pengaruh Inflasi, Likuiditas, Variabilitas Laba terhadap Beta Saham Perusahaan Manufaktur yang terdaftar di Bursa Efek Indonesia Periode 2010-2013", Jurnal Ilmiah Wahana Akuntansi, Vol 10. No.1.

Silalahi, Esli, 2015, "Pengaruh Faktor Fundamental Perusahaan terhadap Risiko Investasi pada Perusahaan Go Publik di Bursa Efek Indonesia", Jurnal Akuntansi, Vol I. No. 1 ISSN: $2443-1079$.

Sugiyono, 2018, Metode Penelitian Kuantitatif, ALFABETA, Bandung.

Tandelilin, Eduardus, 2017, Pasar Modal Manajemen Portofolio dan Investasi”, PT Kanisius, YogyakartaTim Penyusun, 2018, Pedoman Skripsi, STIE YPPI Rembang, Rembang. 
INOBIS: Jurnal Inovasi Bisnis dan Manajemen Indonesia

Volume 04, Nomor 01, Desember 2020

Siti Ko'imah, Damayanti

Werastuti, Desak Nyoman Sri dan Ni Made Estiyanti, 2015, "Pengaruh Sumber Pembiayaan dari Utang, Likuiditas, Pertumbuhan Aset, Profitabilitas, Rasio Pembayaran Deviden terhadap Beta saham", Jurnal Manajemen \& Akuntansi STIE Triatma Mulya, Vol. 21.No.1.

www.idx.co.id

www.pefindo.com

Yulia dan Hotman T. Pohan, 2015, "Faktor-Faktor Fundamental yang Mempengaruhi Beta Saham pada Perusahaan Non Keuangan yang terdaftar di BEI", Jurnal Magister Akuntansi Trisakti (e-Journal, Vol II, No. 2. ISSN: 2339-0859. 